Karakuş Tayşi, E. ve Özbay, M. (2016) Ortaokul Öğrencileri İçin Dinlemeye Yönelik Tutum Ölçeğinin Geliştirilmesi: Geçerlilik ve Güvenilirlik Çalışması. Ana Dili Eğitimi Dergisi, 4(2), 187-199.

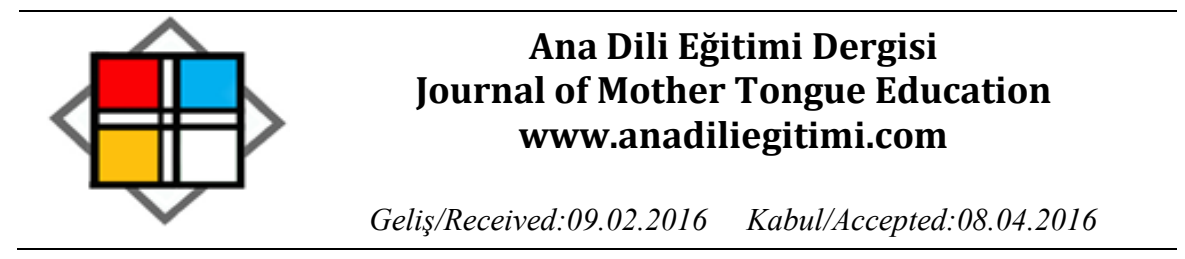

\title{
Ortaokul Öğrencileri İçin Dinlemeye Yönelik Tutum Ölçeğinin Geliştirilmesi: Geçerlilik ve Güvenilirlik Çalışması ${ }^{1}$
}

\author{
Esra KARAKUŞ TAYŞi \\ Murat ÖZBAY ${ }^{3}$
}

\begin{abstract}
Öz
Bu çalışmanın amacı ortaokul (6-7-8) öğrencilerinin dinlemeye yönelik tutumlarını ölçmek için "tutum ölçeği" geliştirmektir. Çalışma 613 öğrenci ile gerçekleştirilmiştir. Ölçeğin faktörlerinin belirlenmesi ve güvenirlilik için 364 öğrenciden toplanan veri kullanılmıştır. Açımlayıcı faktör analizi ile ölçeğin 4 faktörlü bir yapıya sahip olduğu belirlenmiştir. Bu dört faktör, varyansın \%48,729'unu açıklamaktadır. Araştırma sonucunda 30 maddeden oluşan bir ölçek ortaya çıkarılmış, Cronbach Alfa güvenirlik katsayısı 0,824 olarak hesaplanmıştır.
\end{abstract}

Anahtar Kelimeler: Dinleme Eğitimi, Dinlemeye Yönelik Tutumlar, Ölçek Geliştirme

\section{The Development of Listening Attitude Scale for Secondary School Students: Study on The Validity and Reliability}

\begin{abstract}
The purpose of this study is developing an attitude scale which used for measuring secondary school students attitudes toward listening. In general the study were performed with 613 students. Factor analysis and reliability analysis data was collected from 364 students. It's determined by exploratory factor analysis that scale has 4 factors. These four factors explained $\% 48,729$ of total variance. At the end of the research, a 30 -item scale was formed, cronbach's alpha was calculated 0,824 .
\end{abstract}

Key Words: listening instruction, attitudes toward listening, Scale Development,

\section{Giriş}

Davranış bilimlerinin anahtar kavramlarından biri olduğu kabul edilen tutum, farklı alanlardaki kuramsal gelişmeleriyle değişik boyutlar ve tanımlamalar kazanmıştır (İnceoğlu, 2004). Ajzen (1989:241) tutumu, kişilerin herhangi bir nesneye, kişiye, olaya, kuruma veya kişinin dünyasının ayırt edilebilir bir yönüne yönelik olumlu ya da olumsuz tepki verme eğilimi olarak ifade etmektedir. Tutum kavramı, olayların, durumların, nesnelerin vb. bireyleri olumlu veya olumsuz olarak etkilemesi sonucu bireyde meydana gelen davranışsal, zihinsel, duygusal eğilimlerdir şeklinde tanımlanabilir.

\footnotetext{
${ }^{1}$ Bu çalışma “Öğrenme Stiline Dayalı Eğitimin Ortaokul Öğrencilerinin Dinlediğini Anlama Becerilerine ve Dinlemeye Yönelik Tutumlarına Etkisi” isimli doktora tezinden üretilmiştir.

${ }^{2}$ Dr., Dumlupınar Üniversitesi, Eğitim Fakültesi, Türkçe Eğitimi Bölümü, Kütahya. E-posta:

esra.karakus@dpu.edu.tr

${ }^{3}$ Prof. Dr., Gazi Üniversitesi, Eğitim Fakültesi, Türkçe Eğitimi Bölümü, Ankara. E-posta: mozbay@gazi.edu.tr
} 
Tutumlar, bireyin düşünce, davranış ve duygusal eğilimlerinin uyumlu olmasını sağlamaktadır. Tutumlar hem sosyal algıyı hem de davranışları etkilediği için sosyal psikolojinin temel konularından biri olmuştur (Kağıtçıbaşı, 2010). Söz konusu insan davranışı olunca eğitimde tutum kavramının öneminin göz ardı edilemeyecek kadar büyük olduğu kabul edilmektedir. Bu nedenle eğitimciler, insan davranışlarına etki eden, onunla ilişkisi olan tutum gibi değişkenleri araştırmak, anlamak, bilmek istemişlerdir (Tavşancıl, 2010: 1).

Tutumların sadece duygu ya da davranış eğilimi olarak düşünülmemesi duyuşsal, davranışsal ve bilişsel olarak üç boyutuyla bir bütün olarak ele alınması gerektiği uzmanlar tarafından üzerinde durulan bir konu olmuştur. Güçlü ve yerleşmiş yapıda olan tutumlarda bu ögeler tam anlamıyla bulunmakla birlikte daha zayıf olan tutumlarda davranışsal ögeler daha düşük seviyede olabilmektedir. Farklı ögelerden oluştuğu için tutum karmaşık bir yapı olarak karşımıza çıkmaktadır. Ögeler ise tutumu kendi içerisinde tutarlılığı olan bir sistem hâline getirir. Böylece bireyin çevresindeki çeşitli objelere, olaylara vb. karşı besledikleri duyguları, onlarla ilgili düşünceleri, bilgileri ve onlara yönelik oluşturduğu davranışları tutarlılık ve devamlııı gösterir (Kağıtçıbaşı, 2010: 109112).

Son yıllarda yapılan araştırmalarda tutumun oluşabilmesi için bu üç ögenin de bulunmasının gerekli olmadığı düşüncesi ortaya konulmuştur. Birey düşündüğü, bildiği bir bilgiyi davranışa dönüştürmeyebilir. Bu türde farklı yaklaşımlara rağmen sosyal bilimlerde eskiden beri kabul gören tutumların üç ögeden oluştuğu tezi hâlen ve çoğunlukla kabul gören bir yaklaşımdır. Tutumların oluşmasında zihinsel değerlendirmeler, asgari şart olarak kabul edilmektedir. Ancak, bireylerin zamanla geliştirdikleri yerleşik tutumları daha sonra davranış ve duyguya yönelik ögeleri de içermektedir (Eagly, Chaiken, 1993: Akt: Kağıtçıbaşı, 2010: 114-115).

Tutumlar, birçok psikolojik değişken gibi gözlenip ölçülemeyen, varlığı davranışsal ve sözel belirtilerden anlaşılan psikolojik değişkenlerdir. Tutumların ortaya çıkacak davranışı etkilediği varsayılarak davranışa yol açtığı söylenebilir (Arkonaç, 2001: 157). Tutumlar incelendiğinde, hem işleyişine yönelik birtakım çıkarımlar yapılarak davranışların önceden tahmin edilme imkânı hem de tutum değişimi sürecinin koşulları tespit edilerek tutumlar kontrol altına alınıp insan davranışının denetimi sağlanmış olacaktır (İnceoğlu, 2004: 54). Bu bilgilerden yola çıkarak, "Tutumlar tek başlarına davranışı meydana getirebilirler mi? Bir kişinin bir durum, olay vb. hakkındaki tutumları bilinirse, o konudaki davranışı önceden tahmin edilebilir mi?" sorularına cevap aramamız gerekmektedir. Bu soruların cevabı eğer olumlu ise özellikle sosyal bilimler açısından önemli veriler elde edilmesini sağlar. Tutumların ölçülmesinin önemi de artar. Tutumlarla ilgili araştırma yaparken neyin ölçmek istendiği ve ne tür sorular sorulması gerektiği doğru tespit edilmelidir (Kağıtçıbaşı, 2010: 115-118). 
Ortaokul Öğrencileri İçin Dinlemeye Yönelik Tutum Ölçeğinin Geliştirilmesi: Geçerlilik ve Güvenilirlik Çalışması

Tutumlar davranışların oluşmasında önemli bir etkendir ve tutumların sağlıklı bir biçimde ölçülmesiyle davranışın daha iyi tahmin edilmesi sağlanabilir. Tutumların, doğuştan gelmediği, ilk olarak anne-babadan etkilenerek oluştuğu ardından çocuğun sosyal çevreyle etkileşime girmesiyle deneyim, medya, arkadaşlar vb. gibi etkenlerle birlikte öğrenildiği söylenebilir.

Tutumların davranışlara yön veren etkenler arasında yer aldığı ve doğuştan değil sonradan yaşantı yoluyla kazanıldığı dikkate alındığında eğitim-öğretim sürecinin tutumların oluşmasında ve gelişmesinde ne kadar önemli olduğu anlaşılmaktadır. Dinlemenin de bu süreçte en çok kullanılan beceri olduğu düşünülürse bireylerin dinlemeye yönelik olumlu tutum geliştirmeleri bütün hayatlarını olumlu anlamda etkileyecektir.

Öğrenciler, dinleme sürecinde kolaylıkla pasif kalabiliyorlar. Bu pasiflik sonucunda da sıkılıp dinlemeye karşı isteksiz hale gelebiliyorlar. Bu yüzden öğrencilerin dinlemeye yönelik tutumlarını olumlu yönde geliştirmeleri, dinleme becerisinin gelişimi açısından büyük önem taşımaktadır (Goh ve Taib:2006)

Dinleme anlık bir tutumun sonucunda bireyin işitsel uyaranları algılamasıdır. Bir başka ifadeyle, dinleme, kişi tarafından işitilen bir şeyin anlaşılmasıdır. Bu yönüyle dinlemenin de, okuma, konuşma, gözlem vb. gibi bir öğrenme yolu olduğu söylenebilir ve okuldaki öğrenmelerin büyük çoğunluğu da dinleme yolu ile gerçekleşir (Özbay, 2005: 91).

Günlük hayatta ve okul hayatında pek çok bilgi dinleyerek elde edilir. Daha doğmadan gelişmeye başlayan dinleme becerisi, başarının ve öğrenmenin anahtarıdır. İyi bir dinleme gerçekleşmeden iyi konuşmaya ve yazmaya da imkân yoktur. Dinlemeye sadece örgün eğitimde ihtiyaç duymayız, çalışma ortamlarında kurulan arkadaşlık gibi bireysel ilişkilerin de olumlu yönde gelişmesinde etkisi büyüktür. Sizi iyi bir dinleyici olarak tanıyan insanlar kendileriyle ilgili konuları sizinle konuşabileceklerini; onları dinleyerek sorunlarını çözmede yardımcı olacağınızı, düşüncelerine katılmasanız bile kendilerini anladığınızı belirteceğinizi, saygılı olacağınızı bilirler (Özbay, 2009: 64; Mackay, 1997:9).

Görüldüğü gibi dinleme yalnızca bir öğrenme aracı değildir, sosyal yaşamda bireyler arasındaki ilişkilerin düzenlenmesinde de etkin bir role sahiptir. Fikirleri, istekleri, duyguları ve intiyaçları karşılıklı olarak birbirine iletmek amacıyla başvurulan dinleme, bireysel, sosyal ve toplumsal ilişkilerde başarılı olmanın da ön şartıdır. Dinleme becerisinin gelişmesi, birbirlerinin duygularını, düşüncelerini anlayan, problem çözme becerileri, öz güvenleri, kendilerine yönelik algıları, yorumlama kabiliyetleri gelişmiş bireylerin yetişmesinde önemli rol oynar.

Dinleme süreci birçok faktörü içinde barındıran çok yönlü bir beceri olduğundan dinleyici de bununla doğru orantılı farklı tutumlar geliştirir. Önemli olan bu tutumların olumlu anlamda gelişme göstermesidir. Aksi takdirde hayatın bu denli merkezinde olan dinlemeye yönelik olumsuz tutumlara 
sahip olmak önce eğitim ortamlarında, sonra sosyal ortamlarda başarısızlığı beraberinde getirir. Bundan dolayı tüm derslerde, özellikle de Türkçe derslerinde dinleme çalışmalarına gereken önem verilmelidir. Dinleme becerisini geliştirmeye yönelik çalışmalar, öğrencilerin bireysel farklılıkları, sınıf seviyeleri, ilgi duydukları konular dikkate alınarak yapıldığında dinlemeye yönelik tutumların gelişme gösterdiği görülmüştür. Katrancı'nın (2012) “Üstbiliş stratejileri öğretiminin dinlediğini anlama becerisine ve dinlemeye yönelik tutuma etkisi" adlı çalışmasının sonuçları da bunu destekler niteliktedir.

\section{Yöntem}

Bu çalışma, Dinlemeye Yönelik Tutum Ölçeğinin yapı geçerliliğini ve iç tutarlılık güvenirlik katsayısını belirlemeye yönelik olarak hazırlanan ölçekleme temelli bir araştırmadır.

\section{Araştırma Grubu}

Ölçeğin geliştirilmesi sırasında nitel veri toplamada 102 öğrenci, ön uygulamada 144 öğrenci, madde düzeltmede 3 öğrenci, asıl uygulamada 364 öğrenci olmak üzere Ankara Merkez ilçelerinde bulunan 5 farklı ortaokuldan tesadüfî yöntemle seçilen toplam 613 ortaokul 6-7-8.sınıf öğrencisi ile çalışılmıştır.

\section{Veri Toplama Araçları}

Geliştirilecek ölçekte yer alacak tutum maddelerini oluşturmak için farklı ortaokulda okuyan 102 öğrenciden kompozisyon yazdırarak nitel veri toplanmıştır. Ölçeğin geliştirilmesinde alınan diğer veri ise ön uygulama sonrasında oluşturulan ve 51 maddelik 5'li Likert tipi deneme ölçeğinin 364 ortaokul öğrencisine uygulanmasıyla elde edilmiştir.

\section{Verilerin Toplanması}

Ortaokul öğrencilerinin dinlemeye yönelik tutumlarının ölçülmesi amacıyla geliştirilecek ölçekte yer alacak tutum maddelerini oluşturmak için üç farklı ortaokulda okuyan 102 öğrenciden dinleme konulu kompozisyon yazdırarak nitel veri toplanmıştır.

Bu yazılardan yola çıkılarak toplam 51 maddelik bir havuz oluşturulmuştur. Yazdırılan bu maddeler 3 ölçme değerlendirme ve 5 Türkçe eğitimi uzmanı tarafından incelenmiştir. Uzmanlar, bu süreçte maddeleri, tutumları ölçmesi, tutum dışındaki diğer psikolojik faktörleri yansıtmaması, dinlemeye yönelik tutum maddeleri olması, ölçekte yer alması uygun görülen maddelerin tutumların olumlu veya olumsuz yönlerini yansıtan tutum maddesi olup olmadığını belirlemeleri yönünden değerlendirmiştir. Uzmanların incelemesi sonucunda 8 madde elenmiş, 4 madde de düzeltilmiş ve toplam 43 madde taslak ölçeğe alınmıştır.

Madde havuzundan uzmanlarca seçilen 43 tutum maddesinden oluşan "Hiç Katılmıyorum", "Katılmıyorum" , "Kısmen Katılıyorum" , "Katılıyorum" ve "Tamamen Katılıyorum" şeklinde 5'li likert tipinde taslak olarak hazırlanan ölçekte yer alan ifadelerin öğrenciler tarafından anlaşılabilir olup 
Ortaokul Öğrencileri İçin Dinlemeye Yönelik Tutum Ölçeğinin Geliştirilmesi: Geçerlilik ve Güvenilirlik Çalışması

olmadığının görülmesi için 144 ortaokul öğrencisine ön uygulama yapılmıştır. Bu uygulamalar araştırmacı tarafından yürütülmüş ve uygulamalar aşamasında öğrencilerden gelen sorular değerlendirmeye alınmıştır. Öğrenci görüşlerinden hareketle ve elde edilen verilerin analizi sonucunda 9 madde taslak ölçekten çıkarılmıştır. 34 maddelik deneme ölçeğinin madde düzeltme çalışmaları ve ölçekte bulunan maddelerinin hepsinin hedef kitledeki bütün öğrenciler tarafından tam ve net olarak anlaşılıp anlaşılmadığını görmek için ön uygulamanın yapıldığı okullarda okuyan, bu uygulamaya katılmayan ve bir önceki yılda Türkçe ders notu orta düzeyde olan üç 7. sınıf öğrencisi tesadüfî bir şekilde seçilmiştir. Bu öğrencilerle birebir çalışılarak deneme ölçeğindeki maddeler öğrencilere teker teker sesli olarak okutulmuştur. Öğrencilere okudukları her maddeden sonra o maddeyle ilgili anlayıp anlamadıklarını ölçen sorular sorulmuş ve açıklamalar yaptırılmıştır. Uygulama sonucunda öğrenciler maddeleri anladıklarını belirterek aynı yönde açıklamalar yapmıştır, yalnızca bir maddeyi üç öğrencinin de farklı yorumladıkları görülerek bu madde ölçekten çıkarılmıştır. Böylece $25^{\prime} i$ olumlu, $8^{\prime} i$ ise olumsuz ifadelerden oluşan toplam 33 maddelik ölçek deneme uygulaması için hazır hâle getirilmiştir.

Deneme ölçeğinin asıl uygulamasını yapmak için Ankara ili merkezinde bulunan 5 farklı okulda öğrenim gören 364 ortaokul (6-7-8) öğrencisine ulaşılmıştır. Ölçek araştırmacı tarafından uygulanmıştır. Uygulamalardan önce ölçek hakkında kısa bir bilgilendirme yapılmış ve sorular öğrencilere tek tek okunmuştur.

Uygulamadan sonra toplanan veriler incelenerek eksik ya da fazla işaretleme gibi problemlerin tespit edildiği 19 ölçek değerlendirme dışında bırakılmıştır. Değerlendirme, 6.sınıftan 114; 7.sınıftan 118, 8.sınıftan 113 öğrenci olmak üzere toplam 345 öğrenciden alınan veri üzerinden yapılmıştır.

\section{Verilerin Analizi}

Alınan verilerden hareketle, açıklayıcı faktör analizi ve madde ayırt edicilik yapılarak ölçeğin güvenirlik katsayıları hesaplanmıştır. Analiz sonuçlarına göre 30 maddelik dört faktörlü bir ölçek elde edilmiştir.

Toplanan verilerin analizi için önce cevaplayıcı matrisleri oluşturulup ölçekte yer alan olumlu ve olumsuz maddeler tespit edilmiş, olumsuz olan maddeler olumlu maddelerin tersine puanlanmıştır.

\section{Bulgular}

Ölçeğin güvenirliği için madde toplam puan korelasyonu incelenmiştir. Bu korelasyon test maddelerinden alınan puanlarla testin toplam puanı arasındaki ilişkiyi açıklar. Madde toplam korelasyonu 0.30 ve üzeri olan maddelerin ayırt ediciliği yüksektir (Büyüköztürk, 2007). Yapılan analiz 
sonucunda hiçbir maddenin toplam puan korelasyonunun 0.30 'un altında kalmadığı görülmüştür. Tablo 1'de ölçekteki maddelere ilişkin madde analizi sonuçları verilmiştir.

Tablo 1. Dinlemeye Yönelik Tutum Ölçeğinin Madde Analizi

\begin{tabular}{|c|c|c|c|}
\hline $\begin{array}{l}\text { Denemelik } \\
\text { Madde No }\end{array}$ & Ölçek & Ölçek Madde No & $\begin{array}{l}\text { Madde Toplam } \\
\text { Korelasyonları }\end{array}$ \\
\hline 2 & & 1 & ,436 \\
\hline 3 & & 2 & 378 \\
\hline 6 & & 3 & 413 \\
\hline 8 & & 4 & ,353 \\
\hline 12 & & 5 &, 554 \\
\hline 16 & & 6 &, 432 \\
\hline 17 & & 7 &, 590 \\
\hline 20 & & 8 &, 451 \\
\hline 21 & & 9 & ,426 \\
\hline 22 & & 10 & ,375 \\
\hline 24 & & 11 & 436 \\
\hline 26 & & 12 &, 511 \\
\hline 27 & & 13 & ,605 \\
\hline 28 & & 14 & ,446 \\
\hline 29 & & 15 & ,464 \\
\hline 30 & & 16 & ,471 \\
\hline 32 & & 17 &, 578 \\
\hline 4 & & 18 & ,474 \\
\hline 5 & & 19 & ,316 \\
\hline 9 & & 20 & ,395 \\
\hline 10 & & 21 & ,489 \\
\hline 25 & & 22 & ,398 \\
\hline 11 & & 23 & ,479 \\
\hline 13 & & 24 &, 527 \\
\hline 18 & & 25 & ,409 \\
\hline 23 & & 26 & ,302 \\
\hline 7 & & 27 & ,401 \\
\hline 19 & & 28 & ,336 \\
\hline 31 & & 29 & ,519 \\
\hline 33 & & 30 & ,484 \\
\hline
\end{tabular}

Daha sonra ölçeğin güvenilirlik katsayısına bakılmıştır. Güvenilirlik katsayısını hesaplamanın yolları, değişkenlerin kaynağına, türüne ve uygulama sayısına göre değişiklik gösterir (Hambleton, Swaminathan ve Rogers, 1991). Hesaplama yolunun farklılı̆ı (Bock, Aitkin, 1981:443), güvenilirlik katsayısının yorumsal anlamını da değiştirir. Güvenirlilik, 0 ilâ +1 arasında değişen değerler alır ancak; +1'e yakın değerler alması istenir (Andrich,1989: 8). Ölçme aracının her bir maddesi 1 ilâ 5 arasında likert tipi ölçeklendiğinden iç tutarlııık katsayısını hesaplayabilmek için Cronbach Alpha $(\alpha)$ güvenilirlik katsayısı kullanılmıştır. Ölçeğin Cronbach Alpha güvenirlik katsayısı 0,824 çıkmıştır. Özdamar (2004)’a göre Cronbach Alpha katsayısı 0.80 ile 1.00 arasında olan ölçeğin güvenirliliği yüksek derecededir. Buna göre ölçeğin Cronbach Alpha katsayısının yeterli olduğu söylenebilir. 
Ortaokul Öğrencileri İçin Dinlemeye Yönelik Tutum Ölçeğinin Geliştirilmesi: Geçerlilik ve Güvenilirlik

\section{Çalışması}

Açımlayıcı faktör analizi yapılmadan önce örneklemin analiz için uygunluğunu test eden Kaiser-Meyer-Olkin(KMO) ve Bartlett testi yapılmıştır. Analiz sonucunda elde edilen Kaiser-MeyerOlkin (KMO) ve Barlett değerleri Tablo 2'de verilmiştir.

Tablo 2: Dinlemeye Yönelik Tutum Ölçeğinin KMO ve Barlett Testi Sonuçları

\begin{tabular}{lcc}
\hline KMO & & .773 \\
\hline Küresel Barlett Testi & Ki-Kare & 1652,796 \\
& Sd & 528 \\
& $\mathrm{p}$ &, 000 \\
\hline
\end{tabular}

Yukarıdaki tabloda KMO değerinin .77 olduğu görülmektedir. Kaiser-meyer-olkin örneklem yeterliliği istatistiğinin 0,50 üzerinde çıkması verilerin örneklem sayısının yeterli olduğunun bir göstergesidir (Hutcheson, Sofroniou, 1999; Osborne, J. W., \& Costello, A. B, 2004). Bu sonuca göre faktör analizi yapmak için örneklem büyüklüğünün yeterli düzeyde olduğu belirlenmiştir. Bartlett testi ise $p=0.000$ şeklinde anlamlı bulunmuştur. Bartlett's küresellik testi ki kare değeri verilerin faktör analizi için uygunluğunu test eder. Elde edilen oran yükseldikçe veri setinin faktör analizi için uygunluğu da bir o kadar artar. Dolayısıyla, bu verilerin korelasyon matrisi için faktör analizine uygun olduğu sonucu ortaya çıkmıştır $(p<0,05)$.

Faktör analizine uygun olduğu kanıtlanan veri setine temel bileşenler analizi yöntemi kullanılarak faktör analizi yapılmıştır.

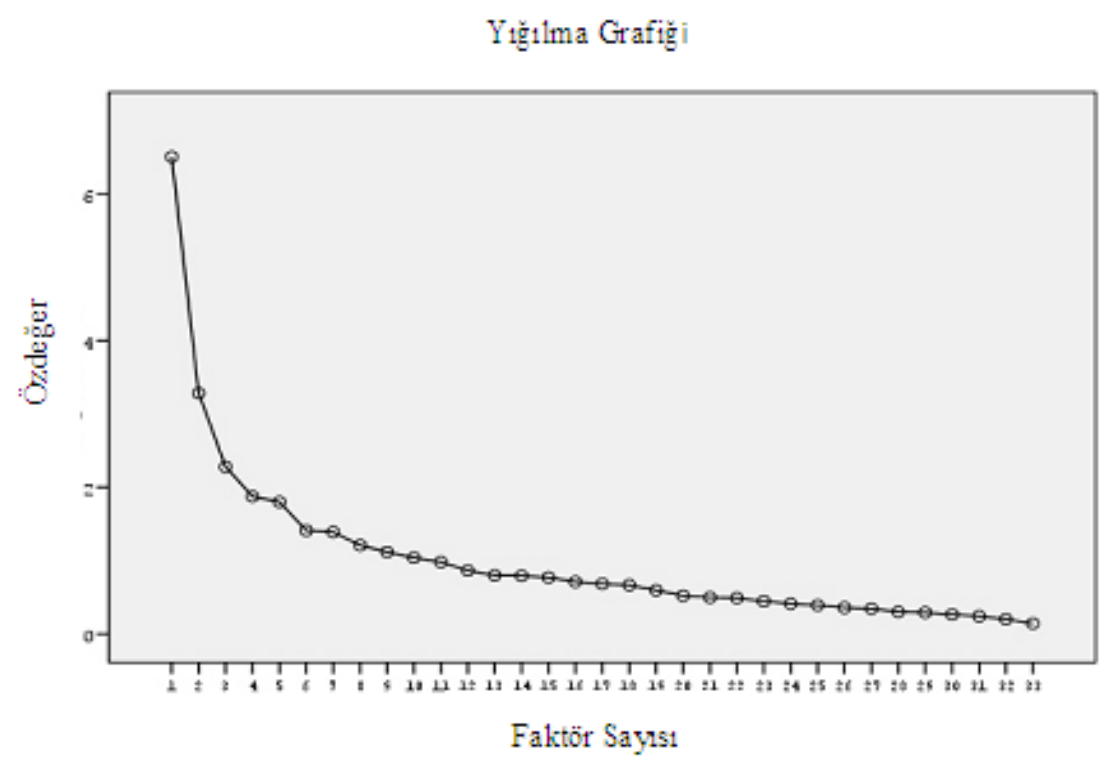

Şekil 1: Dinlemeye Yönelik Tutum Ölçeğinin Yığılma Grafiği

Varimax yöntemiyle döndürülmüş faktör analizi yapılmıştır. Sonuçların değerlendirilmesinde özdeğeri (eigenvalue) 1'in üzerinde olan faktörler anlamlı kabul edilmiştir. Faktör yükleri incelenirken 
minimum değer olarak .45 alınmış, yığılma grafiğinin kırılma noktası da yapıyı belirlerken göz önünde bulundurulmuştur.

Çalışmada toplam varyansın \%50,623'ünün açıklandığı 6 faktörlü bir yapı tespit edilmiştir. Faktör yükü $.45^{\prime}$ in altında olan 1 ve 15 . maddeler ve kuramsal olarak anlamlı kümelenmediği için de 14. madde ölçekten çıkarılarak ölçeğe toplam 30 madde alınmıştır.

Döndürme işleminden sonra ölçekten madde çıkarılmış ve faktör analizi tekrar yapılmıştır. Analiz sonucunda toplam varyansın $\% 48,729$ 'unu açıklayan 4 faktörlü bir yapı elde edilmiştir. Sosyal bilimlerde toplam açıklanan varyansın en az \% 45 olması yeterlidir (Büyüköztürk, 2001). Döndürme sonrası ölçekteki 17 madde birinci faktörde, 5 madde ikinci faktörde, 4 madde üçüncü faktörde, 4 maddede dördüncü faktörde toplanmıştır. Tablo 3'te seçilen maddelerin faktör yükleri verilmiştir.

Tablo 3: Dinlemeye Yönelik Tutum Ölçeğine Seçilen Maddelerin Faktör Yükleri

\begin{tabular}{|c|c|c|c|c|c|}
\hline $\begin{array}{c}\text { Denemelik } \\
\text { Ölçek Madde } \\
\text { No }\end{array}$ & $\begin{array}{c}\text { Ölçek } \\
\text { Madde } \\
\text { No }\end{array}$ & 1.Faktör & 2.Faktör & 3.Faktör & 4. Faktör \\
\hline 2 & 1 &, 534 & & & \\
\hline 3 & 2 & ,459 & & & \\
\hline 6 & 3 & ,509 & & & \\
\hline 8 & 4 & ,674 & & & \\
\hline 12 & 5 & ,640 & & & \\
\hline 16 & 6 & ,522 & & & \\
\hline 17 & 7 & ,632 & & & \\
\hline 20 & 8 & 609 & & & \\
\hline 21 & 9 & ,584 & & & \\
\hline 22 & 10 & ,463 & & & \\
\hline 24 & 11 &, 563 & & & \\
\hline 26 & 12 &, 577 & & & \\
\hline 27 & 13 & ,603 & & & \\
\hline 28 & 14 & ,451 & & & \\
\hline 29 & 15 & ,649 & & & \\
\hline 30 & 16 &, 579 & & & \\
\hline 32 & 17 & ,605 & & & \\
\hline 4 & 18 & & ,731 & & \\
\hline 5 & 19 & & ,597 & & \\
\hline 9 & 20 & & ,562 & & \\
\hline 10 & 21 & & ,598 & & \\
\hline 25 & 22 & & ,589 & & \\
\hline 11 & 23 & & & ,553 & \\
\hline 13 & 24 & & & ,622 & \\
\hline 18 & 25 & & & ,462 & \\
\hline 23 & 26 & & & 631 & \\
\hline 7 & 27 & & & & ,799 \\
\hline 19 & 28 & & & & 837 \\
\hline 31 & 29 & & & & ,467 \\
\hline \multirow[t]{2}{*}{33} & 30 & & & & ,614 \\
\hline & & $\begin{array}{l}\text { Dinlemeyi } \\
\text { Gerekli } \\
\text { Görme } \\
\end{array}$ & $\begin{array}{c}\text { Dinlemede } \\
\text { Bireysel } \\
\text { Farklılıklar }\end{array}$ & $\begin{array}{l}\text { Dinleme } \\
\text { Güçlüğü }\end{array}$ & $\begin{array}{c}\text { Etkili Dinleme } \\
\text { Alışkanlığı }\end{array}$ \\
\hline
\end{tabular}


Ortaokul Öğrencileri İçin Dinlemeye Yönelik Tutum Ölçeğinin Geliştirilmesi: Geçerlilik ve Güvenilirlik Çalışması

Ölçekte yer alan maddelerin faktör yükleri Tablo 3’te görüldüğü gibi ,451 ile ,837 arasında değişmektedir. Büyüköztürk (2007)'e göre ölçekteki maddelerin faktör yük değerlerinin 0.45 ya da daha yüksek olması madde seçimi için iyi bir ölçüdür.

Dört faktörlü ölçeğin yapısı incelendiğinde birinci faktördeki on yedi madde "dinlemeyi gerekli görme"yi, ikinci faktördeki maddeler "dinlemedeki bireysel farklılıklar"ı, üçüncü faktördeki dört madde "dinleme güçlüğ̈̈"nü, dördüncü faktördeki dört madde de "etkili dinleme alışkanlığı"nı içermektedir.

\section{Tartışma}

Araştırmada, dinlemeye yönelik tutum ölçeğinin geçerliğini ve güvenirliğini belirlemeye yönelik yapılan analizler sonucunda, 30 maddelik 4 faktörden oluşan likert tipi bir araca ulaşılmıştır. Ölçeğin bütün maddelerinin dinlemeye yönelik olumlu ve olumsuz tutuma sahip olan öğrencileri tespit ettiği görülmüştür.

DYTÖ’nün güvenirliği ise Cronbach Alfa katsayısı, madde-toplam korelasyonları ile incelenmiştir. Madde-toplam korelasyonunu yorumlamada ölçüt alınabilecek sınır değerler dikkate alındığında, madde toplam korelasyonu 0.30 ve üzeri olan maddelerin ayırt ediciliğinin yüksek olduğu bilinmektedir (Büyüköztürk, 2006). Madde-toplam korelasyonlarına ilişkin değerler incelendiğinde, hiçbir maddenin toplam puan korelasyonunun 0.30 'un altında kalmadığı görülmüştür. Ölçeğin Cronbach Alpha güvenirlik katsayısı 0,824 olarak hesaplanmıştır. Özdamar (2004)'a göre Cronbach Alpha katsayısı 0.80 ile 1.00 arasında olan ölçeğin güvenirliliği yüksek derecededir. Buna göre ölçeğin Cronbach Alpha katsayısının güvenirlilik bakımından yeterli olduğu söylenebilir.

DYTÖ’nün yapı geçerliliğini incelemek amacıyla açımlayıcı faktör analizi yapıımıştır. Analiz sonucunda toplam varyansın $\% 48,729$ 'unu açıklayan 4 faktörlü bir yapı elde edilmiştir. Sosyal bilimlerde toplam açıklanan varyansın en az \% 45 olmasının yeterli (Büyüköztürk, 2001) olduğuna ilişkin ölçüte dayanarak, yapı ortaokul öğrencilerinin dinlemeye yönelik tutumlarını ölçmek için yeterli bulunmuştur. Maddelerin faktör yükleri de ,451 ile ,837 arasında değişmektedir.

Ölçeğin dört faktörlü yapısı incelendiğinde, birinci faktörde yer alan on yedi maddenin "dinlemeyi gerekli görme"yle, ikinci faktördeki maddelerin "dinlemedeki bireysel farklılıklar"la, üçüncü faktördeki dört maddenin "dinleme güçlügü̈yle, dördüncü faktördeki dört maddenin de “etkili dinleme alışkanlığı”yla ilgili olduğu görülmüştür.

Toplam 30 maddeden oluşan Dinlemeye Yönelik Tutum Ölçeğinde 7 olumsuz ve 23 olumlu madde yer almaktadır. Hazırlanan bu ölçekten en yüksek 150, en düşük 30 puan alınabilir.

Araştırmanın yapıldığı dönemde ortaokul öğrencilerinin (6-7-8.sınıf) dinlemeye yönelik tutumlarını ölçmek için kullanılabilecek bir ölçme aracına rastlanmamıştır. Bu ölçek ortaokul 
öğrencilerinin dinleme becerisine yönelik tutumlarının belirlenmesine, bu yönde yapılacak çalışmalar için geliştirilecek ölçme araçlarına katkı sağlayabilir.

DYTÖ, ortaokul 6-7 ve 8. sınıf öğrencilerine yönelik olarak geliştirilmiştir. Gerekli geçerlik ve güvenirlik çalışmaları yapılarak farklı sınıf düzeylerindeki öğrenciler için de uygulanabilir.

\section{Kaynakça}

Ajzen, I., (1989). Attitude Structure and Behavior. Attitude Structure and Function, (Edt.Pratkanis A.R.; Breckler, S.J.;Greenwald, A. G.) New Jersey: Lawrence Erlbaum Associates,Publishers.

Andrich, D. (1989). Distinctions between assumptions and requirements in measurement in the social sciences.(Ed. In J.A. Keats, R. Taft, R.A. Heath, S.H. Lovibond) Mathematical and Theoretical Systems, (pp. 7-16). North Holland: Elsevier Science Publishers.

Arkonaç, S.A. (2001). Sosyal psikoloji, Değiştirilmiş ve Genişletilmiş 2. Baskı, i̇stanbul: Alfa Basım Yayım Dağııım.

Bock, R.D., \& Aitkin, M. (1981). Marginal maximum likelihood estimation of item parameters: Application of an EM algorithm. Psychometrika , 46, 443-459.

Büyüköztürk, Ş. (2001). Deneysel desenler. Ankara: PegemA Yayıncılık.

Büyüköztürk, Ş. (2007). Sosyal bilimler için veri analizi el kitabı. (7.Baskı). Ankara: PegemA Yayıncılık.

Goh, C., and Taib, Y. (2006). Metacognitive instruction in listening for young learners. ELT Journal, 60(3), 222232.

Hambleton, R. K., Swaminathan, H., \& Rogers, H. J. (1991). Fundamentals of item response theory. Newbury Park, CA: Sage.

Hutcheson G. D., Sofroniou N.(1999). The Multivariate social scientist: introductory statistics using generalized linear models sage publications: London, Thousand Oaks, New Delhi.

inceoğlu, M. (2004). Tutum, algı, iletişim. Ankara: Elips Kitap.

Kağıtçıbaşı, Ç. (2010). Günümüzde insan ve insanlar (12. Baskı). İstanbul: Sistem Matbaacılık.

Katrancı, M. (2012). Üstbiliş stratejileri öğretiminin dinlediğini anlama becerisine ve dinlemeye yönelik tutuma etkisi. Ankara: Hacettepe Üniversitesi Sosyal Bilimler Enstitüsü İlköğretim Ana Bilim Dalı Yayımlanmamış Doktora Tezi.

Mackay, I. (1997). Dinleme becerisi. Ankara: Illkkaynak Kültür ve Sanat Ürünleri.

Osborne, J. W. and Costello A. B. (2004). Sample size and subject to item ratio in principal components analysis. Practical Assessment, Research \& Evaluation, 9(11).

Özbay, M. (2005). Bir dil becerisi olarak dinleme eğitimi. Ankara: Öncü Kitap.

Özbay, M. (2009). Anlama teknikleri - II: dinleme eğitimi. Ankara: Öncü Kitap.

Özdamar, K. (2004). Paket programlar ile istatistiksel veri analizi 1-2. Eskişehir: Kaan Kitabevi.

Tavşancıl, E. (2010). Tutumların Ölçülmesi ve SPSS ile Veri Analizi (4.Baskı). Ankara: Nobel Yayınları. 
Ortaokul Öğrencileri İçin Dinlemeye Yönelik Tutum Ölçeğinin Geliştirilmesi: Geçerlilik ve Güvenilirlik Çalışması

\section{Eki: DiNLEME BECERISINE YÖNELIK TUTUM ÖLÇEĞi}

\section{DINLEMEYI GEREKLI GÖRME}

1. Dinlemeyle ilgili etkinlikleri yapmak hoşuma gider.

Hiç Katılmıyorum Katılmıyorum Kısmen Katılıyorum Katılıyorum Tamamen Katılıyorum

2. Metinleri dinlemenin zihnimi geliştirdiğine inanırım.

Hiç Katılmıyorum Katılmıyorum Kısmen Katılıyorum Katılıyorum Tamamen Katılıyorum

3. Metinleri kendim okumayı daha çok severim.

Hiç Katılmıyorum Katılmıyorum Kısmen Katılıyorum Katılıyorum Tamamen Katılıyorum

4. Bir metni dinlediğimde o metne yönelik soruları daha iyi ve anlayarak cevaplarım.

Hiç Katılmıyorum Katılmıyorum Kısmen Katılıyorum Katılıyorum Tamamen Katılıyorum

5. Herhangi bir metni dinlerken kendimi iyi hissederim.

Hiç Katılmıyorum Katılmıyorum Kısmen Katılıyorum Katılıyorum Tamamen Katılıyorum

6. Dinlerken, anlatılanları gözümde canlandırdığım için daha kolay anlarım.

Hiç Katılmıyorum Katılmıyorum Kısmen Katılıyorum Katılıyorum Tamamen Katılıyorum

7. Dinleme metinleri beni rahatlatıyor.

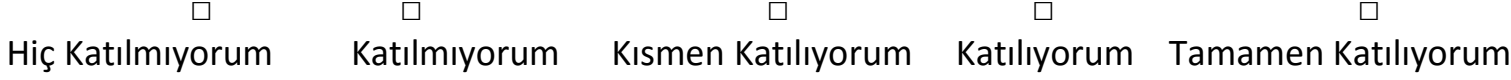

8. Dinleme becerimin diğer derslerdeki başarımı olumlu yönde etkileyeceğini düşünüyorum.

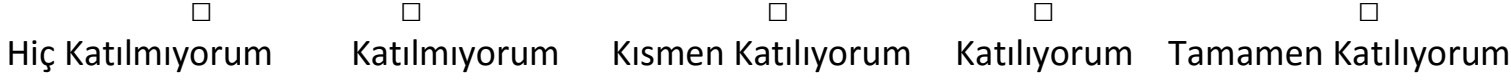

9. Dinleme metinlerinden canlandırma yapıldığında daha çok zevk alırım.

Hiç Katılmıyorum Katılmıyorum Kısmen Katılıyorum Katılıyorum Tamamen Katılıyorum

10. Metni dinledikten sonra metinle ilgili soruları cevaplamayı severim.

Hiç Katılmıyorum Katılmıyorum Kısmen Katılıyorum Katılıyorum Tamamen Katılıyorum

11. Metinler vurgu ve tonlamaya dikkat edilerek okunduğunda zevk alarak dinlerim.

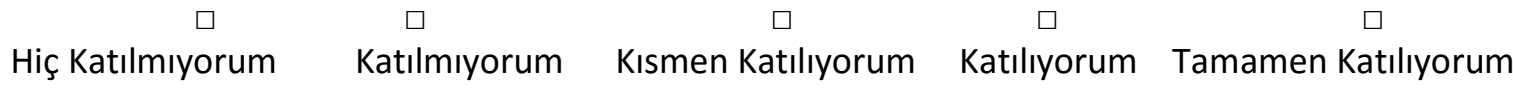

12. Benden farklı düşüncelere sahip olsalar da karşımdakileri dinlerim. 
Hiç Katılmıyorum

Katılmıyorum

Kısmen Katılıyorum

Katılıyorum Tamamen Katılıyorum

13. İnsanlar konuşurken onları dikkatle dinlerim.

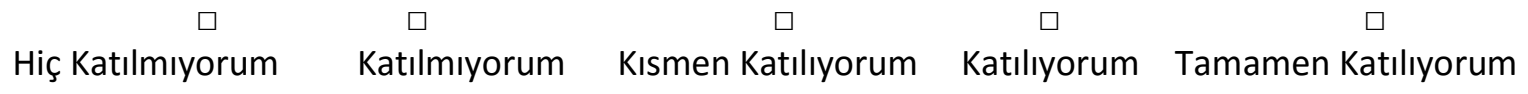

14. Başkalarını ilgiyle dinlerim.

Hiç Katılmıyorum Katılmıyorum Kısmen Katılıyorum Katılıyorum Tamamen Katılıyorum

15. Dinlerken kendimi konuların içinde hissederim.

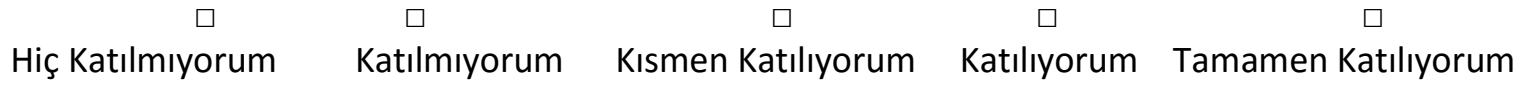

16. Dinlemekten hoşlanırım.

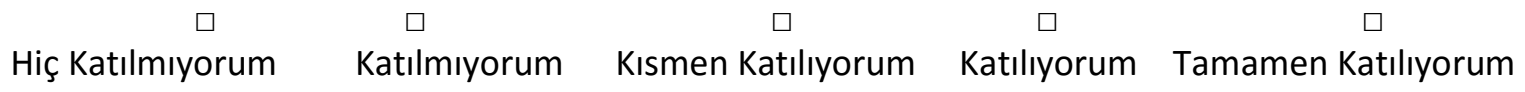

17. Günlük hayatta dinlemenin önemli bir yeri vardır.

Hiç Katılmıyorum Katılmıyorum Kısmen Katılıyorum Katılıyorum Tamamen Katılıyorum

\section{DINLEMEDE BIREYSEL FARKLILIKLAR}

18. Metinleri dinlerken dikkatimi toplamakta güçlük çekerim.

Hiç Katılmıyorum Katılmıyorum Kısmen Katılıyorum Katılıyorum Tamamen Katılıyorum

19. Metni başka biri okuduğunda anlamakta zorlanırım.

Hiç Katılmıyorum Katılmıyorum Kısmen Katılıyorum Katılıyorum Tamamen Katılıyorum

20. Dinlediğim metni ilk seferde anlamakta güçlük çekerim.

Hiç Katılmıyorum Katılmıyorum Kısmen Katılıyorum Katılıyorum Tamamen Katılıyorum

21. Metni dinlerken düşüncelerimi toplamakta zorlanırım.

Hiç Katılmıyorum Katılmıyorum Kısmen Katılıyorum Katılıyorum Tamamen Katılıyorum

22. Metin iki defa veya daha fazla okunduğunda daha iyi anlarım.

Hiç Katılmıyorum Katılmıyorum Kısmen Katılıyorum Katılıyorum Tamamen Katılıyorum

\section{DINLEME GÜçLÜĞÜ}

23. Metinleri sonuna kadar dinlerken genellikle çok sıkılırım.

Hiç Katılmıyorum Katılmıyorum Kısmen Katılıyorum Katılıyorum Tamamen Katılıyorum

24. Metinleri dinlerken genellikle dalgınımdır. 
Ortaokul Öğrencileri İçin Dinlemeye Yönelik Tutum Ölçeğinin Geliştirilmesi: Geçerlilik ve Güvenilirlik Çalışması

Hiç Katılmıyorum Katılmıyorum Kısmen Katılıyorum Katılıyorum Tamamen Katılıyorum

25. Dinlediklerim aklımda kalmadığı için dinlemeyi sevmem.

Hiç Katılmıyorum Katılmıyorum Kısmen Katılıyorum Katılıyorum Tamamen Katılıyorum

26. Metinlerin daha yavaş okunmasını isterim.

Hiç Katılmıyorum Katılmıyorum Kısmen Katılıyorum Katılıyorum Tamamen Katılıyorum

\section{ETKILI DINLEME ALIŞKANLIĞı}

27. Dinlemeyi, okumaktan daha çok severim.

Hiç Katılmıyorum Katılmıyorum Kısmen Katılıyorum Katılıyorum Tamamen Katılıyorum

28. Dinleme becerimin geliştirilmesi gerektiğine inanıyorum.

Hiç Katılmıyorum Katılmıyorum Kısmen Katılıyorum Katılıyorum Tamamen Katılıyorum

29. Dinlediğim şeyleri daha iyi hatırlarım.

Hiç Katılmıyorum Katılmıyorum Kısmen Katılıyorum Katılıyorum Tamamen Katılıyorum

30. Dinleyerek daha kolay öğrenirim.

Hiç Katılmıyorum Katılmıyorum Kısmen Katılıyorum Katılıyorum Tamamen Katılıyorum 